\title{
A DELETION INVOLVING INTRON 13 AND EXON 14 OF FACTOR VIII GENE IN A HAEMOPHILIAC WITH ANTI-FACTOR VIII ANTIBODY
}

\author{
Sadaaki Mrkami, Takuya Nishimura, Hiroyuki NaKA, \\ Kuninori Kuze, and Hiromu FukuI \\ Department of Pediatrics, Nara Medical College, \\ Kashihara, Nara 634, Japan.
}

\begin{abstract}
Summary A deletion mutation in the factor VIII gene of a severe haemophiliac patient was found along with a high level of factor VIII inhibitor in the blood plasma among seventy Japanese haemophilia A patients. The $6 \mathrm{kbp}$ long deletion involved a region from somewhere between $P_{S t} \mathrm{I}$ and $S_{S t} \mathrm{I}$ sites at nucleotide positions 2659 and 2991 of exon 14 and intron 13, respectively (nucleotide positions were defined as in Wood et al., 1984).
\end{abstract}

Key Words factor VIII gene, deletion, haemophiliac, inhibitor

\section{INTRODUCTION}

Haemophilia A (classical haemophilia) is one of the most abundunt inherited bleeding disorders caused by genetic deficiency of the coagulation protein, factor VIII. The clinical severity in patients with haemophilia varies mainly due to different levels of factor VIII activity among different families. Moreover, about $10 \%$ of patients with severe haemophilia have high levels of antibodies against factor VIII, so-called factor VIII inhibitor. The genetic heterogeneity of haemophilia patients suggests that many different molecular alterations are involved in the resultant malfunctional factor VIII gene in haemophiliacs. Several point and deletion mutations in the factor VIII gene were observed in Caucasian population (Gitschier et al., 1985, 1986; Antonarakis et al., 1985; Youssoufian et al., 1986, 1987a, 1987b; Higuchi et al., 1987; Bernardi et al., 1987; Matthews et al., 1987).

We report of an example of deletion extending from intron 13 to exon 14 of factor VIII gene in a Japanese patient with haemophilia A and high level of inhibitor.

Received July 12, 1988 ; revised version received August 2, 1988; Accepted August 17, 1988 


\section{CASE REPORT}

The patient (24 years of age, male) showed a severe haemophilia A, having less than $1 \%$ of factor VIII coagulant activity assayed by one stage method (Hardisty and Macpherson, 1962) and less than $0.1 \%$ of factor VIII coagulant antigen assayed by IRMA (Peake et al., 1979). His typical bleeding episodes were the repeated intracranial bleedings. At the age of 17 years, inhibitor against factor VIII developed, and the maximal titers were 74 Bethesda units $/ \mathrm{ml}$. He has no siblings but a normal son. His mother was diagnosed previously to be a carrier $(30 \%$ factor VIII coagulant activity).

\section{METHODS}

Chromosomal DNA was isolated from leukocytes and digested with TaqI, EcoRI, Bam HI, KpnI and Sst I restriction endonucleases. Gel electrophoresis, radioisotope labeling and Southern blotting were performed as previously described (Maniatis et al., 1982). DNA probes used for Southern analysis are shown in Fig. 1. Briefly, (1) probe $A, 1.7 \mathrm{kbp}$ long, delineates exons $1-12$, (2) probe $\mathrm{B}, 4.7 \mathrm{kbp}$ long, delineates exons $14-26$, (3) probe $\mathrm{C}, 1.8 \mathrm{kbp}$, contains the remaining portion of exon 26, (4) probe D, $0.37 \mathrm{kpb}$, contains the portion of exon 14 between EcoRI and $P$ st I sites at positions 2290 and 2658, respectively, (5) probe E, $2.5 \mathrm{kbp}$, contains another portion of exon 14 between two Pst I sites at positions 2659 and 5163 . The probes A, B and C are contained in pSP64, $\mathrm{Ap}^{\mathrm{R}}$ (Antonarakis et al., 1985), kindly provided by Dr. Lewis, Genetics Institute, whilst probes $\mathrm{D}$ and $\mathrm{E}$ are contained in pHSG398, $\mathrm{Cm}^{\mathrm{R}}$ (Takeshita et al., 1987).

\section{RESULTS}

Autoradiographs of Southern blots of normal and patient genomic DNA samples are shown in Fig. 2. The DNA samples digested with TaqI were hybridized to probe A, and those digested with $T a q \mathrm{I}, E c o \mathrm{RI}, B a m \mathrm{HI}$ or $K p n \mathrm{I}$, were hybridized to probes B and C. Probe A detected several fragments of $8.0 \mathrm{kbp}$ (exons 3-4), 4.3 $\mathrm{kbp}$ (exon 7), $2.4 \mathrm{kbp}$ (exon 11), $2.2 \mathrm{kbp}$ (exon 1), $1.8 \mathrm{kbp}$ (exons 7-9) and $1.4 \mathrm{kbp}$ (exon 2) in length. The size of these fragments were all normal (data not shown).

The use of probes $\mathrm{B}$ and $\mathrm{C}$ revealed fragments of different size in patient DNA when digested with TaqI, Eco RI, Bam HI and KpnI. In normal subject, TaqI digestion showed $9.2 \mathrm{kbp}$ (exon 26), $5.9 \mathrm{kbp}$ (exon 14 and exons 20-22), $2.8 \mathrm{kbp}$ (exons 15-18, exons 24-25 and exon 26), $2.4 \mathrm{kbp}$ (exon 23), $2.2 \mathrm{kbp}$ (exons 18-19) and 1.4 $\mathrm{kbp}$ (exons 23-24) fragments (Gitschier et al., 1985). In patient, the major $5.9 \mathrm{kbp}$ fragment that corresponds to exon 14, was replaced by a smaller fragment of 4.9 kbp. In EcoRI digestion of patient DNA, the major fragment of $4.8 \mathrm{kbp}$ (exon 14) 


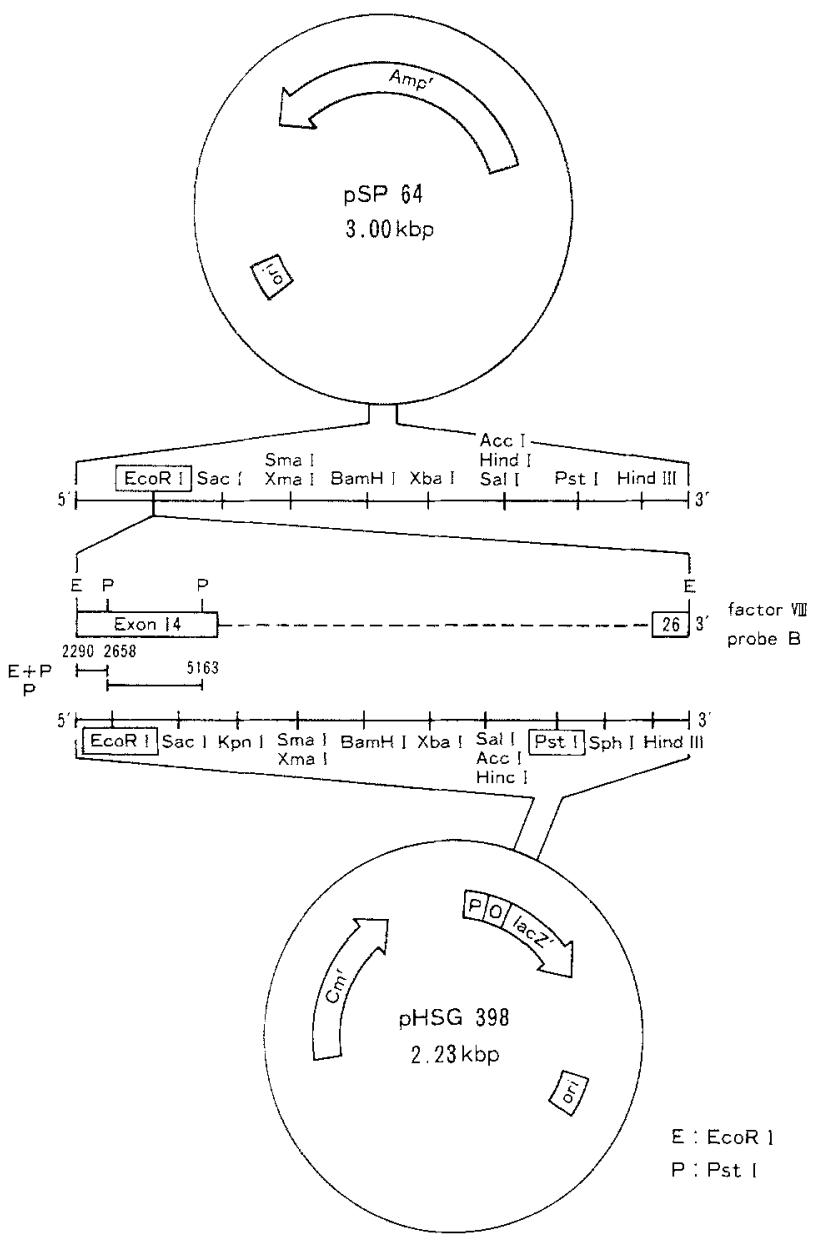

Fig. 1. Probes $\mathrm{D}$ and E. Probe B inserted in pSP64 was restricted with either EcoRI + Pst I or Pst I. Subfragments inserted into pHSG398, were cultured and screened. Probes $\mathrm{D}$ and $\mathrm{E}$ were obtained by gel electrophoresis.

was undetectable. Bam $\mathrm{HI}$ digestion showed a new fragment and a normal-sized $0.6 \mathrm{kbp}$ fragment of exon 14 . KpnI digestion also showed a new fragment.

Probe D detected no band in patient DNA by Bam HI digestion, and probe $\mathrm{E}$ detected a new fragment of $5.9 \mathrm{kbp}$ by EcoRI digestion in addition to the $3.2 \mathrm{kbp}$ fragment by Sst I digestion (Fig. 3). Disappearance of the $4.8 \mathrm{kbp}$ major fragment of exon 14, when digested with EcoRI and hybridized with probes B and C, was caused by an overup of the $5.9 \mathrm{kbp}$ abnormal fragment derived from exon 14 and $5.9 \mathrm{kbp}$ fragment from exon 26.

From these results, patient factor VIII gene has a partial deletion of approximately $6 \mathrm{kbp}$ to $5^{\prime}$ side from a site between $P_{s t} \mathrm{I}$ site (2659) and Sst I site (2991) in 


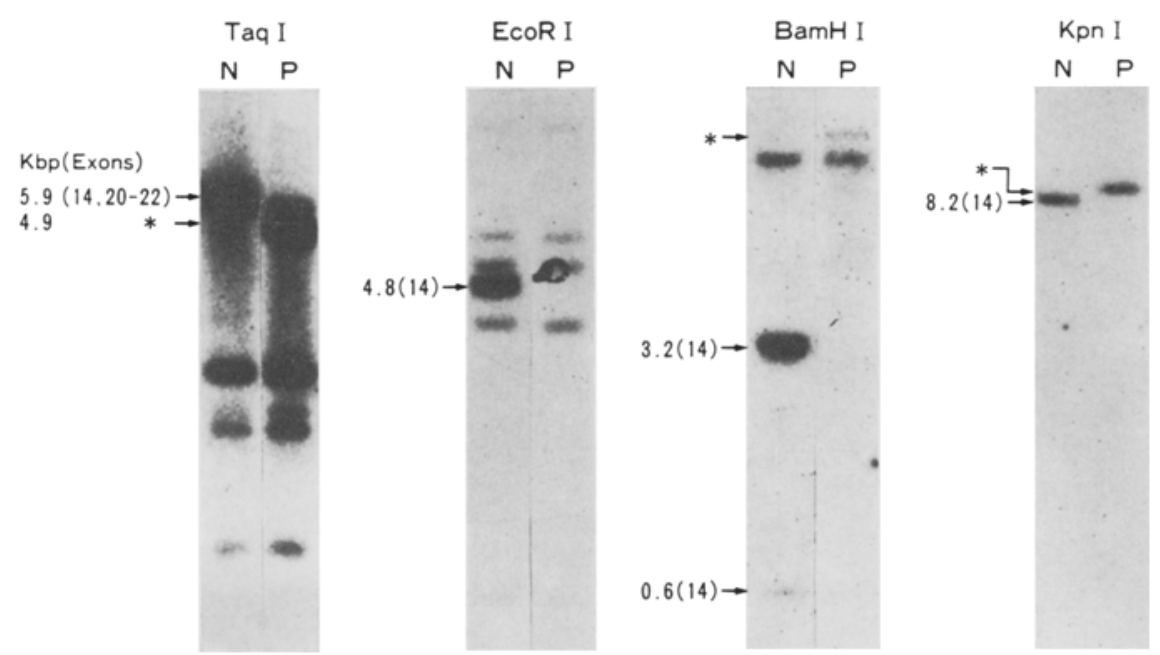

Fig. 2. Southern blots of normal (N) and patient (P) DNAs detected by factor VIII cDNA probes $\mathrm{B}+\mathrm{C}$. Asterisks show abnormal fragments in patients DNA.

exon 14, according to the restriction map of factor VIII gene (Gitschier et al., 1984; Wood et al., 1984).

\section{DISCUSSION}

It was clear by the use of cDNA probes for factor VIII DNA that a severe Japanese haemophilia A patient with high titers of inhibitor has a intragenic deletion of factor VIII gene. From Southern blot analysis and the restriction map of factor VIII gene (Gitschier et al., 1984, 1985; Wood et al., 1984), gene deletion in the patient DNA includes a part of exon 14, accounting for approximately $6 \mathrm{kbp}$ in length.

So far, more than 10 cases of gene deletion have been reported in Caucasian haemophilia A patients (Table 1). As far as the gene deletion of exon 14 is concerned, a small deletion of $2.5 \mathrm{kbp}$ or $2.0-2.5 \mathrm{kbp}$ was not involved in the occurrence of an antibody (inhibitor) against factor VIII (Youssoufian et al., 1987a; Higuchi et al., 1987). However, a large deletion of $12-14 \mathrm{kbp}$ containing exon 14 caused inhibitor (Higuchi et al., 1987). On the other hand, it was reported that several nonsense mutations in exons of factor VIII gene resulted in the development of inhibitor (Gitschier et al., 1985; Higuchi et al., 1987; Matthews et al., 1987; Mikami et al., 1988). Therefore, it will be important to characterize the association between gene defects and epitope specificity of inhibitor against factor VIII.

Factor VIII gene has $186 \mathrm{kbp}$ in length including 26 exons and exon 14 encodes a large part of factor VIII amino acid sequence, called B domain (Gitschier et al., 1984), including thrombin cleavage sites in both ends. This domain connects $\mathrm{A}_{2}$ and $\mathrm{A}_{3}$ domains that play important roles for factor VIII coagulant activity (Vehar 


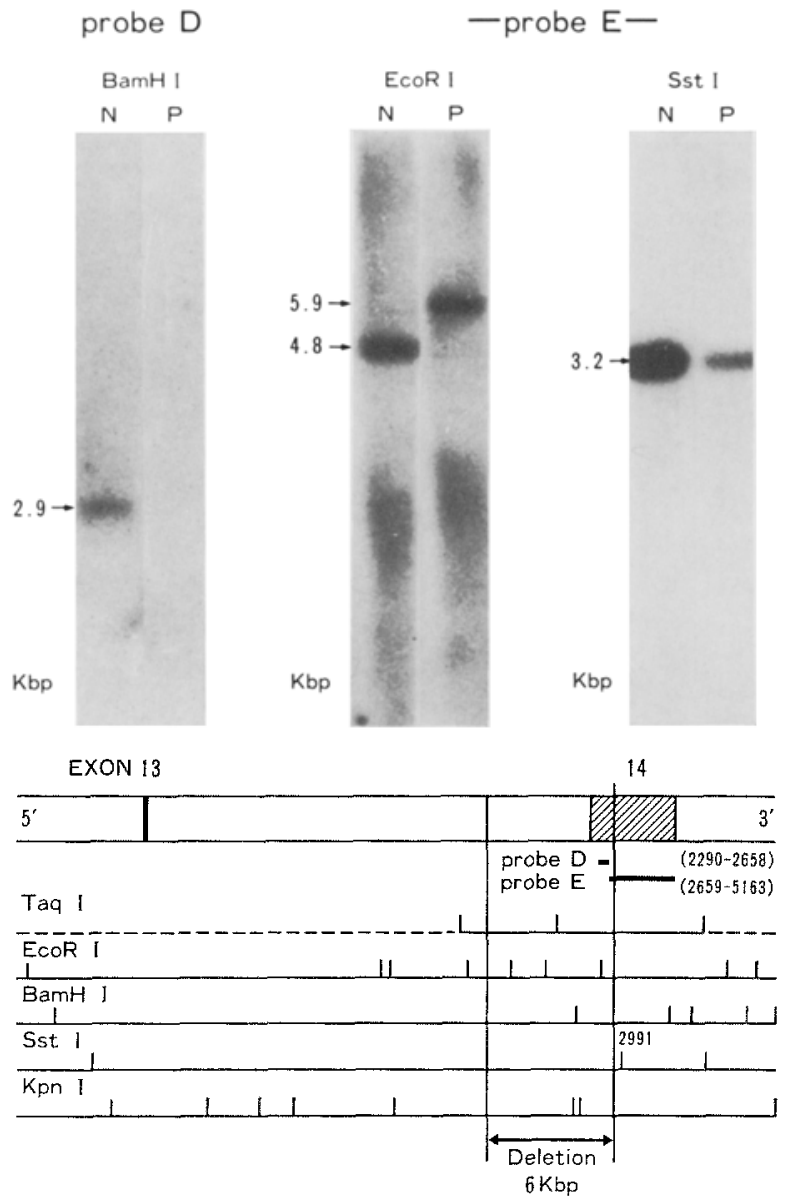

Fig. 3. Southern blots by exon 14 probes (probes $D$ and $E$ ) and a local restriction map of factor VIII gene.

et al., 1984). Toole et al. (1986) demonstrated that factor VIII cDNAs deficient in $\mathrm{B}$ domain polypeptide, when inserted into mammalian cell expression vector, directed the synthesis of biologically active factor VIII. The patient, whose DNA had deletion in the region of exon 14, shows neither factor VIII coagulant activity nor autologous antigen specificity. In summary, we examined 64 Japanese haemophilia A patients and 6 cases with inhibitor. Among these, one case of gene deletion was detected.

Acknowledgments We thank Dr. Lewis in Genetics Institute (Massachusetts, USA) for providing gene probes for factor VIII, and Dr. Hashimoto in Pharma Research Laboratories, Hoechst Japan for providing pHSG plasmid. We also acknowledge the valuable help of Drs. Murotsu and Tokino in Institute for Molecular and Cellular Biology, Osaka University. 
Table 1. Gene deletion of factor VIII in haemophiliac patients.

All cases except for a mild form (*) reported are severe form.

\begin{tabular}{lccc}
\hline & Exon & Deletion & Inhibitor \\
\hline Gitschier et al. $(1985)$ & $23-25$ & $39.0 \mathrm{~kb}$ & $(+)$ \\
Gitschier et al. $(1985)$ & 26 & $21.9 \mathrm{~kb}$ & $(-)$ \\
Antonarakis et al. $(1985)$ & $11-22$ & $80 \mathrm{~kb}$ & $(+)$ \\
Youssoufian et al. $(1987)$ & 6 & $7 \mathrm{~kb}$ & $(-)$ \\
Youssoufian et al. $(1987)$ & 14 & $2.5 \mathrm{~kb}$ & $(-)$ \\
Youssoufian et al. $(1987)$ & $24-25$ & $7 \mathrm{~kb}$ & $(-)$ \\
Youssoufian et al. $(1987)$ & $23-25$ & $16 \mathrm{~kb}$ & $(-)$ \\
Youssoufian et al. $(1987)$ & $22^{*}$ & $5.5 \mathrm{~kb}$ & $(-)$ \\
Higuchi et al. $(1987)$ & $1-5$ & $>35 \mathrm{~kb}$ & $(-)$ \\
Higuchi et al. $(1987)$ & 3 & $1.2-1.7 \mathrm{~kb}$ & $(-)$ \\
Higuchi et al. $(1987)$ & $7-9$ & $15-20 \mathrm{~kb}$ & $(+)$ \\
Higuchi et al. $(1987)$ & 14 & $2.0-2.5 \mathrm{~kb}$ & $(-)$ \\
Highchi et al. $(1987)$ & 14 & $12-14 \mathrm{~kb}$ & $(+)$ \\
Higuchi et al. $(1987)$ & 26 & $\geq 1.8 \mathrm{~kb}$ & $(-)$ \\
Bernardi et al. $(1987)$ & 26 & & $(-)$ \\
Bernardi et al. $(1987)$ & 26 & & $(-)$ \\
Casarino et al. $(1986)$ & $1-26$ & $>210 \mathrm{~kb}$ & $(-)$ \\
Din et al. (1986) & $23-26$ & & $(+)$ \\
Camerino et al. $(1986)$ & $15-18$ & $15 \mathrm{~kb}$ & $(+)$ \\
Youssoufian et al. $(1987)$ & 26 & $2 \mathrm{~kb}$ & $(-)$ \\
\hline
\end{tabular}

\section{REFERENCES}

Antonarakis, S.E., Waber, P.G., Kittur, S.D., Patel, A.S., Kazazian, H.H., Jr., Mellis, M.A., Counts, R.B., Stamatoyannopoulos, G., Bowie, E.J.W., Fass, D.N., Pittman, D.D., Wozney, J.M., and Toole, J.J. 1985. Hemophilia A. Detection of molecular defects and of carriers by DNA analysis. New Engl. J. Med. 313: 842-848.

Bernardi, F., Bertagnolo, V., Bartolai, S., Rossi, L., Panicucci, F., and Conconi, F. 1987. A point mutation and a gene deletion of factor VIII gene in severe haemophilia A. Thromb. Haemostas. 58: 345 (Abst.).

Camerino, G., Bardoni, B., Sampietro, M., Romano, M., Crapanzano, C., and Mannucci, D.M. 1986. Deletion of part of coagulation factor VIII in a hemophiliac with inhibitor. Ric. Clin. Lab. 16: 227 (Abst.).

Casarino, L., Pecorana, M., Mori, P.G., Morfini, M., Mancuso, G., Scrivano, L., Molinari, A.C., Lanza, T., Giavarella, G., Loi, A., Perseu, L., Cao, A., and Pirastu, M. 1986. Molecular basis for hemophilia A in Italians. Ric. Clin. Lab. 16: 227 (Abst.).

Din, N., Schwartz, M., Kruse, T., Vestergaard, S.R., Ahrens, P., Scheibel, E., Nordfang, O., and Ezban, M. 1986. Factor VIII gene specific probes used to study heritage and molecular defects in hemophilia A. Ric. Clin. Lab. 16: 182 (Abst.).

Gitschier, J., Wood, W.I., Goralka, T.M., Wion, K.L., Chen, E.Y., Eaton, D.H., Vehar, G.A., 
Capon, D.J., and Lawn, R.M. 1984. Characterization of the human factor VIII gene. Nature 312: 326-330.

Gitschier, J., Wood, W.I., Tuddenham, E.G.D., Shuman, M.A., Goralka, T.M., Chen, E.Y., and Lawn, R.M. 1985. Detection and sequence of mutations in factor VII gene of haemophiliacs. Nature 315: 427-430.

Gitschier, J., Wood, W.I., Shuman, M.A., and Lawn, R.M. 1986. Identification of a missense mutation in the factor VIII gene of a mild hemophiliac. Science 232: 1415-1416.

Hardisty, R.M. and Macpherson, J.C. 1962. A one-stage factor VIII (antihemophilic globulin) assay and its use on venous and capillary plasma. Thromb. Diathes. Haemmorrh 7: 215-229.

Higuchi, M., Kochhan, L., Schwaab, R., Brackmann, H.H., Egli, H., and Olek, K. 1987. Detection of mutations in hemophilia A. Thromb. Haemostas. 58: 336 (Abst.).

Maniatis, T., Fritsch, E.F., and Sambrook, J. 1982. Molecular Cloning: A Laboratory Manual. Cold Spring Harbor Laboratory, New York.

Matthews, R.J., Peake, I.R., and Bloom, A.L. 1987. Point-mutation of factor VIII coding sequences in haemophilia A. Thromb. Haemostas. 58: 336 (Abst.).

Mikami, S., Nishimura, T., Naka, H., Kuze, K., Fukui, H., Tone, M., and Hashimoto Gotoh, T. 1988. Nonsense mutation in factor VIII gene of a haemophiliac patient with anti-factor VIII antibody. Jpn. J. Human Genet. 33: 409-415.

Peake, I.R., Bloom, A.L., Giddings, J.C., and Ludlam, C.A. 1979. An immunoradiometric assay for procoagulant factor VII antigen: Results in haemophilia, von Willebrand's disease and fetal plasma and serum. Br. J. Haematol. 42: 269-281.

Takeshita, S., Sata, M., Toba, M., Masahashi, W., and Hashimoto-Gotoh, T. 1987. High-copynumber and low-copy-number plasmid vectors for lacZ $\alpha$-complementation and chloramphenicolor kanamycin-resistance selection. Gene 61: 63-74.

Toole, J.J., Pittman, D., Murtha, P., Wasley, L.C., Wang, J., Amphlett, G., Hewick, R., Foster, W.B., Kamen, R., and Kaufman, R.J. 1986. Exploration of structure-function relationships in human factor VIII by site-directed mutagenesis. In 1986 Cold Spring Harbor Symposia on Quantitative Biology, Vol. LI, Cold Spring Harbor Laboratory, New York, pp. 543-549.

Vehar, G.A., Keyt, B., Eaton, D., Rodriguez, H., O'Brien, D.P., Rotblat, F., Oppermann, H., Keck, R., Wood, W.I., Harkins, R.N., Tuddenham, E.G.D., Lawn, R.M., and Capon, D.J. 1984. Structure of human factor VIII. Nature 312: 337-342.

Wood, W.I., Capon, D.J., Simonsen, C.C., Eaton, D.L., Gitschier, J., Keyt, B., Seeburg, P.H., Smith, D.H., Hollingshead, P., Wion, K.L., Delwart, E., Tuddenham, E.G.D., Vehar, G.A., and Lawn, R.M. 1984. Expression of active human factor VIII from recombinant DNA clones. Nature 312: 330-337.

Youssoufian, H., Kazazian, H.H., Jr., Phillips, D.G., Aronis, S., Tsiftis, G., Brown, V.A., and Antonarakis, S.E. 1986. Recurrent mutations in haemophilia A give evidence for CpG mutation hot-spots. Nature 324: 380-382.

Youssoufian, H., Antonarakis, S.E., Aronis, S., Tsiftis, G., Phillips, D.G., and Kazazian, H.H., Jr. 1987a. Characterization of five partial deletions of the factor VIII gene. Proc. Natl. Acad. Sci. USA 84: 3772-3776.

Youssoufian, H., Patel, A., Phillips, D., Kazazian, H.H., and Antonarakis, S.E. 1987b. Recurrent mutations and unusual deletion in hemophilia A. Thromb. Haemostas. 58: 336 (Abst.). 